\title{
Effects of environmental factors and soil properties on topographic variations of soil respiration
}

\author{
K. Tamai \\ Forestry and Forest Products Research Institute, Tsukuba, Japan \\ Received: 24 August 2009 - Published in Biogeosciences Discuss.: 24 November 2009 \\ Revised: 17 March 2010 - Accepted: 17 March 2010 - Published: 26 March 2010
}

\begin{abstract}
Soil respiration rates were measured along different parts of a slope in (a) an evergreen forest with common brown forest soil and (b) a deciduous forest with immature soil. The effects of soil temperature, soil moisture and soil properties were estimated individually, and the magnitudes of these effects in the deciduous and evergreen forests were compared. In the evergreen forest with common brown forest soil, soil properties had the greatest effect on soil respiration rates, followed by soil moisture and soil temperature. These results may be explained by the fact that different soil properties matured within different environments. It can be argued that the low soil respiration rates in the low parts of the slope in the evergreen forest resulted from soil properties and not from wet soil conditions. In the deciduous forest, soil respiration rates were more strongly affected by soil moisture and soil temperature than by soil properties. These effects were likely due to the immaturity of the forest soil.
\end{abstract}

\section{Introduction}

To estimate carbon uptake in forests, several researchers have compared soil respiration rates with tower-based flux measurements (Davidson et al., 2002; Kominami et al., 2003; Sugawara et al., 2005). However, for scientifically robust comparisons, the soil respiration rates must represent an area as large as the area represented by the tower-based flux. Such a requirement is problematic, because many factors such as topography can cause substantial spatial variation in soil respiration rates.

Studies of spatial variation have been focused on a various scale, ranging from several meters (Kosugi et al., 2007) to a

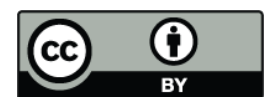

Correspondence to: $\mathrm{K}$. Tamai (a123@ffpri.affrc.go.jp) national scale (Ishizuka et al., 2006). Because most forested areas in Japan involve complex terrain, the topographic scale is extremely important when comparing soil respiration rates with tower-based fluxes.

Soil respiration rates are affected by environmental factors such as soil moisture and soil temperature (Davidson et al., 1998 ) and by soil properties such as root biomass and porosity (Hanson et al., 2000; Dannoura et al., 2006). Therefore, both environmental factors and soil properties can affect topographic variation in soil respiration. Generally, soil moisture declines as elevation along a slope increases. Moreover, due to soil classifications, soil type is often different from each other between low and high parts in a slope. Thus, slope scale should focus on the various topological scales to estimate topological effect on soil respiration.

Spatial variation in soil respiration on slopes has been examined in many forest types including Japanese cedar forests (Ohashi et al., 2007), Japanese cypress forests (Mitani et al., 2006), deciduous broadleaf forests (Hanson et al., 1993; Jia et al., 2003) and tropical rain forests (Sotta et al., 2006; Kosugi et al., 2007). The slope heights in these studies varied substantially (between 7 and $70 \mathrm{~m}$ ), but most studies reported lower soil respiration rates in lower parts of the slopes. Jia et al. (2003), Mitani et al. (2006) and Kosugi et al. (2007) noted that the decreased soil respiration rates on lower slopes were caused by higher soil moisture ratios. However, in a study of a weathered granitic area of southern Kyoto Prefecture, Tamai et al. (2005a) linked lower soil respiration rates in areas of elevated topography to increased dryness. This result shows that the relationship between soil respiration and soil moisture is not unique to any forest and remains unclear.

To ensure that soil respiration rates represent an area as large as the area represented by tower-based fluxes, estimates of the effects of environmental factors and soil properties are necessary (Fang et al., 1998). However, it is important to note that environmental factors and soil properties both

Published by Copernicus Publications on behalf of the European Geosciences Union. 
vary depending on slope locations. Most soil properties such as carbon content, soil microorganisms, root biomass and porosity exist under unique environmental conditions such as soil moisture at each location during the process of soil maturation. Thus, it is impossible to estimate environmental factors and soil properties individually by simply comparing the spatial variations of environmental factors and soil properties with soil respiration.

Some studies have been performed to estimate these variations individually. In a secondary broadleaf forest in northern Japan, Hashimoto et al. (2008) examined the spatial variation of environmental factors such as the soil moisture ratio and physical factors such as the basal area of stems and soil respiration. The researchers concluded that the basal area of stems potentially affects soil respiration via the soil moisture ratio. Palmroth et al. (2005) measured soil respiration rates in adjacent pine plantations and hardwood areas in the Duke Forest, North Carolina, USA. They reported that differences in soil respiration rates were more strongly controlled by the effects of soil temperature than by soil moisture or soil properties.

In this study, the effects of environmental factors including soil moisture and soil temperature and soil property on soil respiration are estimated individually in a slope scale. The effects in an evergreen forest with common forest soil that developed individually under each environmental condition on a slope are compared with the effects in a deciduous forest with very immature soil that is not developed and has similar properties on a slope.

\section{Site Description}

The study sites were located in the Yamashiro. Experimental Forest $\left(34^{\circ} 47^{\prime} \mathrm{N}, 135^{\circ} 51^{\prime} \mathrm{E}\right)$ and the Kahoku Experimental Forest $\left(33^{\circ} 08^{\prime} \mathrm{N}, 130^{\circ} 43^{\prime} \mathrm{E}\right)$ in Japan (Fig. 1a). The Yamashiro forest is a deciduous forest with immature soil, and the Kahoku forest is an evergreen forest with common brown forest soil.

\subsection{Yamashiro experimental forest}

The Yamashiro Experimental Forest has been denuded by heavy logging and soil erosion. The ground surface has been barren with no vegetation for a long time. A picture drawn in the seventeenth century shows that the Yamashiro area had no vegetation at that time (Yamashiro town history editorial board, 1986) and remained bare until erosion control and plantation work was performed after 1875 (Goto et al., 2004). Thus, the soil in this location is immature, even today (Araki et al., 1997). The soils, which originate from granite, are Regosols of sandy loam or loamy sand and contain fine granitic gravel (53\% by weight). Consequently, the surface soil layer at a $5-\mathrm{cm}$ depth has carbon ratios ranging from 38 to $42 \mathrm{mg} \mathrm{g}^{-1}$ (Table 1). Most of the trees planted after 1875 have died, and the area is currently covered by deciduous for-
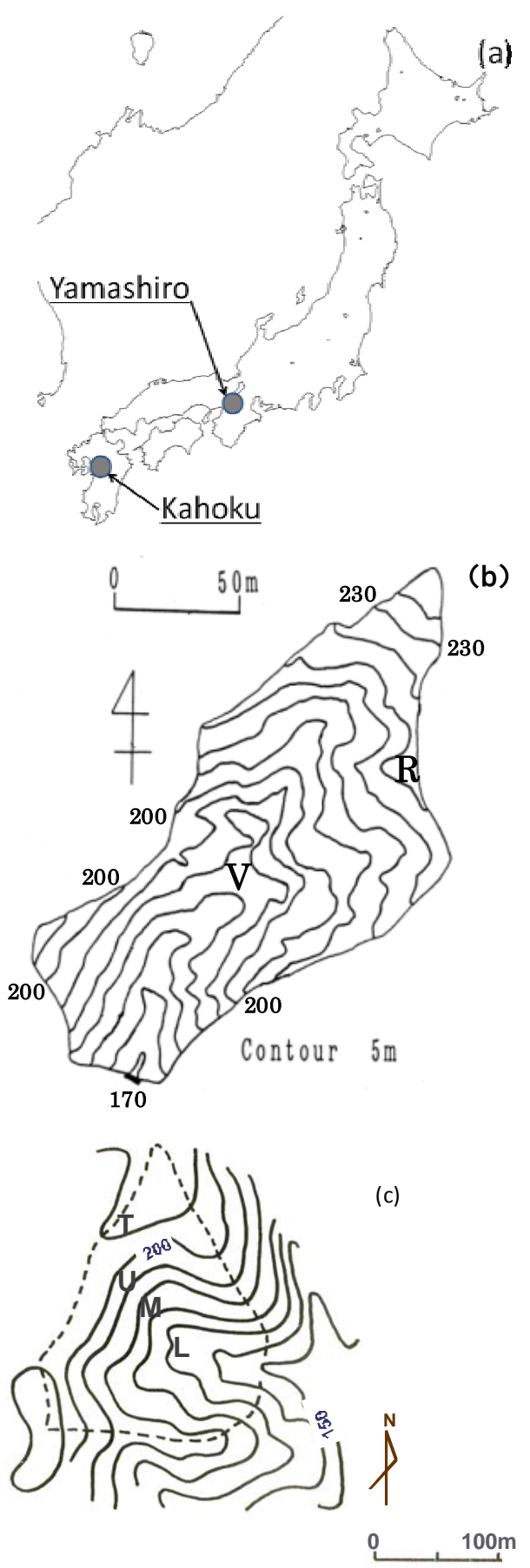

Fig. 1. Location and topography of experimental forest. (a) Location, (b) Topography of Yamashiro Experimental Forest. R and V indicate the location of Plot $\mathrm{R}$ and $\mathrm{V}$, respectively. Numbers show the altitude of contour lines. (c) Topography of Kahoku Experimental Forest. T, U, M and L indicate the location of Plot T, U, M and $\mathrm{L}$, respectively. 
Table 1. Outline of the observation plots.

\begin{tabular}{lclccclc}
\hline $\begin{array}{l}\text { Experimental } \\
\text { Forest }\end{array}$ & $\begin{array}{c}\text { Plot } \\
\text { name }\end{array}$ & $\begin{array}{l}\text { Slope } \\
\text { direction }\end{array}$ & $\begin{array}{c}\text { Slope } \\
\text { angle }\end{array}$ & $\begin{array}{c}\text { Altitude } \\
(\mathrm{m})\end{array}$ & $\begin{array}{c}\text { Basal area } \\
\text { of stem } \\
\left(\mathrm{m}^{2} 100 \mathrm{~m}^{-2}\right)\end{array}$ & $\begin{array}{l}\text { Dominant } \\
\text { species }\end{array}$ & $\begin{array}{c}\text { Total C } \\
\left(\mathrm{mg} \mathrm{g}^{-1}\right)\end{array}$ \\
\hline Yamashiro & $\mathrm{V}$ & $\mathrm{S} \mathrm{53} 3^{\circ} \mathrm{W}$ & $2^{\circ}$ & 188 & 0.131 & Clethra barvinervis & 42 \\
Kahoku & $\mathrm{R}$ & $\mathrm{S} \mathrm{52} 2^{\circ} \mathrm{E}$ & $18^{\circ}$ & 222 & 0.322 & Ilex pedunclosa & 38 \\
& $\mathrm{~B}$ & $\mathrm{~S} 48^{\circ} \mathrm{W}$ & $43^{\circ}$ & 166 & 0.753 & Cryptomeria japonica & 61 \\
& $\mathrm{M}$ & $\mathrm{S} \mathrm{32} 2^{\circ} \mathrm{W}$ & $32^{\circ}$ & 184 & 0.564 & Cryptomeria japonica & 118 \\
& $\mathrm{U}$ & $\mathrm{S} \mathrm{5} 5^{\circ} \mathrm{W}$ & $22^{\circ}$ & 213 & 0.382 & Chamaecyparis obtusa Sieb. et Zucc. & 79 \\
& $\mathrm{~T}$ & $\mathrm{~S} 17^{\circ} \mathrm{E}$ & $6^{\circ}$ & 221 & 3.855 & Chamaecyparis obtusa Sieb. et Zucc. & 79 \\
\hline
\end{tabular}

Table 2. Comparison of the variations in factors between experimental forests.

\begin{tabular}{llll}
\hline $\begin{array}{l}\text { Experimental } \\
\text { Forest }\end{array}$ & $\begin{array}{l}\text { Variation } \\
\text { in topography }\end{array}$ & $\begin{array}{l}\text { Variation } \\
\text { in vegetation }\end{array}$ & $\begin{array}{l}\text { Variation } \\
\text { in Soil property }\end{array}$ \\
\hline Yamashiro & $\begin{array}{l}\text { Remarkable; Altitude } \\
\text { difference is } \approx 30 \mathrm{~m}\end{array}$ & $\begin{array}{l}\text { Slight; All plots is } \\
\text { covered by deciduous species. }\end{array}$ & $\begin{array}{l}\text { Slight; } \\
\text { Extremely immature soil } \\
\text { Kahoku }\end{array}$ \\
$\begin{array}{l}\text { Remarkable; Altitude } \\
\text { difference is } \approx 70 \mathrm{~m}\end{array}$ & $\begin{array}{l}\text { Remarkable; Japanese cedar } \\
\text { (Plot B, M) Japanese cypress (Plot U, T) }\end{array}$ & $\begin{array}{l}\text { Supposed to be remarkable; } \\
\text { matured forest soil }\end{array}$ \\
$\begin{array}{l}\text { Duke } \\
\text { Palmroth et al., 2005) }\end{array}$ & Slight; Slope angle $<5 \%$ & $\begin{array}{l}\text { Remarkable; Hard wood forest } \\
\text { and pine plantation }\end{array}$ & \\
\hline
\end{tabular}

est dominated by oaks. The mean annual precipitation from 1999 to 2002 was $1449.1 \mathrm{~mm}$, with a mean air temperature of $15.5^{\circ} \mathrm{C}$ (Goto et al., 2003).

\subsection{Kahoku experimental forest}

The lower area of the Kahoku Experimental Forest is covered by an approximately 50-year-old Japanese cedar (Cryptomeria japonica) forest and the upper area is covered by a 27- to 50-year-old Japanese cypress (Chamaecyparis obtusa Sieb. et Zucc.) forest. Crystalline schist underlies the watershed. The forest soil is classified as brown forest soil (Cambisol) with a clay loam texture. This soil is common and judged to be more mature than that in Yamashiro. The mean annual precipitation from 1992 to 2003 was $2160 \mathrm{~mm}$, and the mean annual air temperature was $15.4^{\circ} \mathrm{C}$ for the same time period. (Kobayashi and Shimizu, 2007). Detailed soil information has been provided by Ishizuka et al. (2006). The carbon ratios of the soil surface layer are larger than those at Yamashiro, ranging from 78 to $119 \mathrm{mg} \mathrm{g}^{-1}$. The basal area tends to have a larger ratio at the plots at lower altitude, although the carbon ratio does not reflect this tendency as it relates to slope location (Table 1).

\subsection{Comparison of the features of experimental forests}

The features of the experimental forests including the Duke Forest (Palmroth et al., 2005) are summarized in Table 2. These features are compared with those for this study and are presented in the Discussion section.

Altitudinal differences existed at approximately $30 \mathrm{~m}$ and $70 \mathrm{~m}$ in the Yamashiro and Kahoku forests, respectively. Topographic variability was lower in the pine plantation and hardwood plots of the Duke Forest, with $<5 \%$ incline in each (Palmroth et al., 2005).

The difference in vegetation among the plots in Yamashiro is smaller than those in Kahoku and Duke. The Yamashiro Experimental Forest, which is dominated by oaks, exhibits little variation in tree species. Conversely, at the Kahoku Experimental Forest, Plots $\mathrm{L}$ and $\mathrm{M}$ were dominated by Japanese cedar, and Plots $\mathrm{U}$ and $\mathrm{T}$ were dominated by Japanese cypress. The difference in the soil property among the plots is supposed to be the smallest in Yamashiro, where soils are immature because of heavy disturbance in the past. Thus, soil property is supposed to be same in Plots $\mathrm{V}$ and $\mathrm{R}$. In contrast, the soil in Kahoku, which is brown forest soil with an organized soil structure, is supposed to vary greatly among each plot compared to that in Yamashiro. For example, Kobayashi and Shimizu (2007) reported that soil water repellency occurred below a threshold water content of approximately $0.29 \mathrm{~m}^{3} \mathrm{~m}^{-3}$ on the top part of the slope in 
Kahoku. Moreover, the soil in the lower part of the slope in Kahoku includes many fist-sized stones that rolled to the base of the slope and accumulated there.

\section{Observation methodology}

\subsection{Yamashiro experimental forest}

The Yamashiro Experimental Forest is located in a mountainous area and includes an approximately $10-\mathrm{m}$-wide valley with a 30-m-high ridge (Fig. 1b). The plots are $10 \mathrm{~m} \times 10 \mathrm{~m}$. Plot V was at the valley bottom, and Plot $\mathrm{R}$ was on a ridge above the valley (see Table 1 for plot details). The distance between the plots was approximately $70-\mathrm{m}$ horizontally and 30 -m vertically.

The automated chamber system, with a closed static chamber of transparent acrylic, was used to monitor soil respiration at the centre of each plot. The inner space of the chamber had a cross section of $28 \mathrm{~cm} \times 13 \mathrm{~cm}$ and was $13-\mathrm{cm}$ high. A stainless steel collar was inserted into the soil at $10-\mathrm{cm}$ depth, and a motor opened and closed the chamber lid automatically (Tamai et al., 2005b). An infrared gas analyzer (IRGA; GMT222, Vaisala, Finland) and thermocouple enclosed in the chamber monitored the $\mathrm{CO}_{2}$ concentration ratio and air temperature. Nobuhiro et al. (2003) and Tamai et al. (2005b) verified the accuracy of this type of enclosed IRGA chamber. The soil temperature and soil moisture ratio were monitored simultaneously at a 5-cm depth with a SS-201A (Rogu Denshi, Japan) and a HYDRA (Stevens Vitel, USA), respectively, in both plots. No plants were present in the automated chamber. Observations were made from July 2004 to June 2005. Throughout the winter (DecemberMarch), the automated chamber was closed to take measurements at 30-min intervals and then opened and inactive for 150-min intervals. The active and inactive intervals were 12 and $48 \mathrm{~min}$, respectively, for the remaining months. Soil respiration was monitored by the automated chamber at 1-h intervals in summer and 3-h intervals in winter. Analyses were based on the daily average rate.

To investigate spatial variation in the soil respiration rate, measurements were performed around the automated chamber by manually placing an IRGA (GMD-20, Vaisala) enclosed chamber onto eight soil collars set around the automated chamber and inserting it into the soil at a 5-cm depth. The inner space of the chamber was a circle $9.1 \mathrm{~cm}$ in diameter and 13-cm high (Tamai et al., 2005a). No plants were present in the soil collars. The manual chamber observations were performed 11 times at Plot $\mathrm{V}$ and 10 times at Plot R. Manual measurements were taken once or twice a day in the afternoon. The manual chamber was closed for 30 min from December to March and for $12 \mathrm{~min}$ for the other months. The closed times for the automated and manual chambers were 12 or $30 \mathrm{~min}$; these time periods were relatively longer than those in other studies (Mitani et al., 2006;
Kosugi et al., 2007). However, it was confirmed that the $\mathrm{CO}_{2}$ concentration in the chamber increased linearly while below $1300 \mathrm{ppm}$, beyond which $\mathrm{CO}_{2}$ concentration rate tended to decrease (Nobuhiro et al., 2003). The $\mathrm{CO}_{2}$ concentration in the chamber took much longer than 12 or 30 min to increase to around $1300 \mathrm{ppm}$ in this experimental forest (Nobuhiro et al., 2003). Thus, the closed times of 12 or $30 \mathrm{~min}$ did not cause underestimation of Soil respiration.

\subsection{Kahoku experimental forest}

In Kahoku, Plots T, U, M and L were established at the top, upper, middle and lower areas, respectively, of a south-facing slope that was approximately 70-m high (Fig. 1c). Detailed plot information is provided in Table 1 . The plot size was $10 \mathrm{~m} \times 10 \mathrm{~m}$. The soil respiration was measured for 24 soil collars at the centre in each plot using the manual chamber that was used at Yamashiro. Measurements were performed 13 to 14 times in each plot from August 2005 to August 2006. The distances between the collars were around 20 to $30 \mathrm{~cm}$. The frequency was once or twice each month. The closed time of the manual chamber was $30 \mathrm{~min}$ from December to March and $12 \mathrm{~min}$ for other months. The soil temperature (S-TMB, Onset, USA) and soil moisture (S-SMA, Onset) at a 5-cm depth were also monitored. The soil respiration rates presented in this study correspond to the average rates measured for the 24 soil collars in each plot.

\section{Analysis method}

The soil respiration rate was calculated from the soil temperature and soil moisture using Eq. (1) (Tamai et al., 2005b; Palmroth et al., 2005):

$$
F_{p}\left(T_{p}, \theta_{p}\right)=a \operatorname{EXP}\left(b T_{p}\right)\left(\frac{\theta_{p}}{\mathrm{c}+\theta_{p}}\right)
$$

where $F_{p}\left(T_{p}, \theta_{p}\right)$ is the soil respiration rate $\left(\mathrm{mg} \mathrm{CO}_{2} \mathrm{~m}^{-2}\right.$ $\left.\mathrm{s}^{-1}\right), T$ is the soil temperature $\left({ }^{\circ} \mathrm{C}\right)$ at $5-\mathrm{cm}$ depth, $\theta$ is the soil moisture ratio $\left(\mathrm{m}^{3} \mathrm{~m}^{-3}\right)$ at $5-\mathrm{cm}$ depth, and $a, b$ and $c$ are constants. The subscript letter denotes the name of the test plot, with $p=\mathrm{R}, \mathrm{V}, \mathrm{T}, \mathrm{U}, \mathrm{M}$ or $\mathrm{L}$.

The magnitudes of the effects of soil temperature, soil moisture and soil properties on soil respiration rates were estimated individually using Eqs. (2), (3) and (4), respectively:

$$
\begin{aligned}
& E F(T)=F_{c}\left(T_{t}, \theta_{c}\right)-F_{c}\left(T_{c}, \theta_{c}\right) \\
& E F(\theta)=F_{c}\left(T_{c}, \theta_{t}\right)-F_{c}\left(T_{c}, \theta_{c}\right) \\
& E F(\text { Soil })=\mathrm{F}_{\mathrm{t}}\left(\mathrm{T}_{\mathrm{c}}, \theta_{\mathrm{c}}\right)-\mathrm{F}_{\mathrm{c}}\left(\mathrm{T}_{\mathrm{c}}, \theta_{\mathrm{c}}\right)
\end{aligned}
$$

where terms with subscripts $c$ and $t$ refer to parameters for the control plot and test plot, respectively.

Measured values for $T$ and $\theta$ and previously determined values for the constants $a, b$ and $c$ were substituted into the 
relevant terms on the right-hand side of Eqs. (2) through (4) to estimate the magnitude of the effect of each parameter on the soil respiration rate. For example, to estimate the effect of $T$ on the difference in soil respiration rates between the test plot and control plot, values of $a, b, c$ and $\theta$ for the control plot were substituted into both terms of the right-hand side of Eq. (2). Only values of $T$ for test and control plots were substituted into the first and second terms, respectively, of the right-hand side of Eq. (2). Equation (4) can be used to estimate the effect of soil properties on soil respiration rate, because its parameters, $a, b$ and $c$, are thought to represent features of soil properties (Palmroth et al., 2005). Positive, negative and larger absolute values calculated using Eqs. (2) through (4) imply accelerated, suppressed and greater influence, respectively, of each factor on the soil respiration rate.

\section{Results}

\subsection{Yamashiro experimental forest}

Figures $2 \mathrm{a}$ and $\mathrm{b}$ present seasonal variations in the soil respiration rate $(F)$ at Plots $\mathrm{V}$ and $\mathrm{R}$, respectively. Spatial variation in $F$ within each plot was large, with the widest range of values recorded in the manual chamber (approximately $0.2 \mathrm{mg} \mathrm{CO}_{2} \mathrm{~m}^{-2} \mathrm{~s}^{-1}$ ). Nevertheless, the soil respiration rate recorded by the automated chamber and the average respiration rate based on data from the manual chamber were almost identical in every case. These results suggest that the value of $F$ measured with the automated chamber can be regarded as the soil respiration rate for each plot.

$T_{R}$ was slightly higher than $T_{V}$ in winter, and $\theta_{V}$ tended to be slightly higher than $\theta_{R}$ (Fig. 2d). However, this difference was, in general, very small.

Using the minimum total square difference method to estimate the values for the constants in Eq. (1) for Plots R and V, Eq. (1) can be written as Eqs. (5) and (6), respectively:

$$
\begin{aligned}
& F_{R}\left(T_{R}, \theta_{R}\right)=0.1111 \mathrm{EXP}\left(0.1000 T_{R}\right)\left(\frac{\theta_{R}}{0.6752+\theta_{R}}\right) \\
& F_{V}\left(T_{V}, \theta_{V}\right)=0.0424 \mathrm{EXP}\left(0.0878 T_{V}\right)\left(\frac{\theta_{V}}{0.1368+\theta_{V}}\right)
\end{aligned}
$$

The soil respiration rates for Plots $\mathrm{R}$ and $\mathrm{V}$, calculated using Eqs. (5) and (6), respectively, agreed well with the measured soil respiration rates (Fig. 3). The root mean square error between the calculated and observed respiration rates and the ratio between the two over the average observed ratio were $0.0002 \mathrm{mg} \mathrm{CO}_{2} \mathrm{~m}^{-2} \mathrm{~s}^{-1}$ and $1.1 \%$ and $0.0002 \mathrm{mg} \mathrm{CO}_{2} \mathrm{~m}^{-2} \mathrm{~s}^{-1}$ and $1.1 \%$ for Plots $\mathrm{R}$ and $\mathrm{V}$, respectively.

\subsection{Kahoku experimental forest}

$T$ and $\theta$ were compared in each of the four plots (Figs. 4e, f). The results indicate that the measured values of $T$ were almost the same in each of the four plots. However, the measured values of $\theta$ differed greatly between the plots. Plot L generally had the highest $\theta$ values, but the values fluctuated the least within a narrow range of values for $\theta_{L}(0.35-$ $0.45 \mathrm{~m}^{3} \mathrm{~m}^{-3}$ ). The widest range of $\theta$ was recorded at Plot $\mathrm{T}$, where the measured values for $\theta_{T}$ ranged between 0.12 and $0.38 \mathrm{~m}^{3} \mathrm{~m}^{-3}$. Interestingly, while rapid increases in $\theta_{U}, \theta_{M}$ and $\theta_{L}$ were recorded after a precipitation event, no comparable increases in $\theta_{T}$ were measured, particularly during winter. Kobayashi and Shimizu (2007) attributed water repellency in forest soil in the Kahoku Experimental Forest to soil dryness. We also propose soil repellency as the reason for the lack of an observed increase in $\theta_{T}$ following a rainfall event during this study. Indeed, soil moisture differed greatly between the four Kahoku plots.

Using the minimum total square difference method to calculate the constants, Eq. (1) can be rewritten as Eqs. (7, 8, 9 and 10) for Plots T, U, M and L, respectively.

$$
\begin{aligned}
& F_{T}\left(T_{T}, \theta_{T}\right)=0.0904 \mathrm{EXP}\left(0.0619 T_{T}\right)\left(\frac{\theta_{T}}{0.4648+\theta_{T}}\right) \\
& F_{U}\left(T_{U}, \theta_{U}\right)=0.0464 \mathrm{EXP}\left(0.1049 T_{U}\right)\left(\frac{\theta_{U}}{0.6935+\theta_{U}}\right) \\
& F_{M}\left(T_{M}, \theta_{M}\right)=0.0357 \mathrm{EXP}\left(0.0969 T_{M}\right)\left(\frac{\theta_{M}}{0.4716+\theta_{M}}\right) \\
& F_{L}\left(T_{L}, \theta_{L}\right)=0.0159 \mathrm{EXP}\left(0.0890 T_{L}\right)\left(\frac{\theta_{L}}{0.1989+\theta_{L}}\right)
\end{aligned}
$$

The soil respiration rates calculated using Eqs. (7) through (10) agreed well with the observations made at the Kahoku plots (Fig. 5). Seasonal changes in soil respiration rates for Plots T, U, M and L, calculated using Eqs. (7) through (10), are shown in Figs. 4a through d, respectively. The root mean square error between the calculated and observed rates and the ratio of the two over the averaged observed ratio in the four plots were $0.014 \mathrm{mg} \mathrm{CO}_{2} \mathrm{~m}^{-2} \mathrm{~s}^{-1}$ and $14.6 \%$, $0.014 \mathrm{mg} \mathrm{CO}_{2} \mathrm{~m}^{-2} \mathrm{~s}^{-1}$ and $12.7 \%, 0.005 \mathrm{mg} \mathrm{CO}_{2} \mathrm{~m}^{-2} \mathrm{~s}^{-1}$ and $9.9 \%$ and $0.017 \mathrm{mg} \mathrm{CO}_{2} \mathrm{~m}^{-2} \mathrm{~s}^{-1}$ and $16.6 \%$ for Plots $\mathrm{T}$, $\mathrm{U}, \mathrm{M}$ and $\mathrm{L}$, respectively.

\subsection{Spatial variations of the estimated annual soil respiration rates and observed environmental factors}

The annual rate of $F$ was estimated to be $21.56 \mathrm{tCO}_{2} \mathrm{ha}^{-1}$ year $^{-1}$ and $21.10 \mathrm{tCO}_{2} \mathrm{ha}^{-1}$ year $^{-1}$ in Plots $\mathrm{R}$ and $\mathrm{V}$, respectively, in Yamashiro from 1 July 2004 to 30 June 2005 using Eqs. (5) and (6). These two rates are almost equal. These results do not agree with those of Jia et al. (2003), Mitani et al. (2006) and Kosigi et al. (2007), who report that the soil respiration was less at the plots on the lower part of the slope. On the other hand, the annual rate of $F$ was estimated to be $24.79 \mathrm{tCO}_{2} \mathrm{ha}^{-1}$ year $^{-1}, \quad 25.13 \mathrm{tCO}_{2} \mathrm{ha}^{-1}$ year $^{-1}$, 

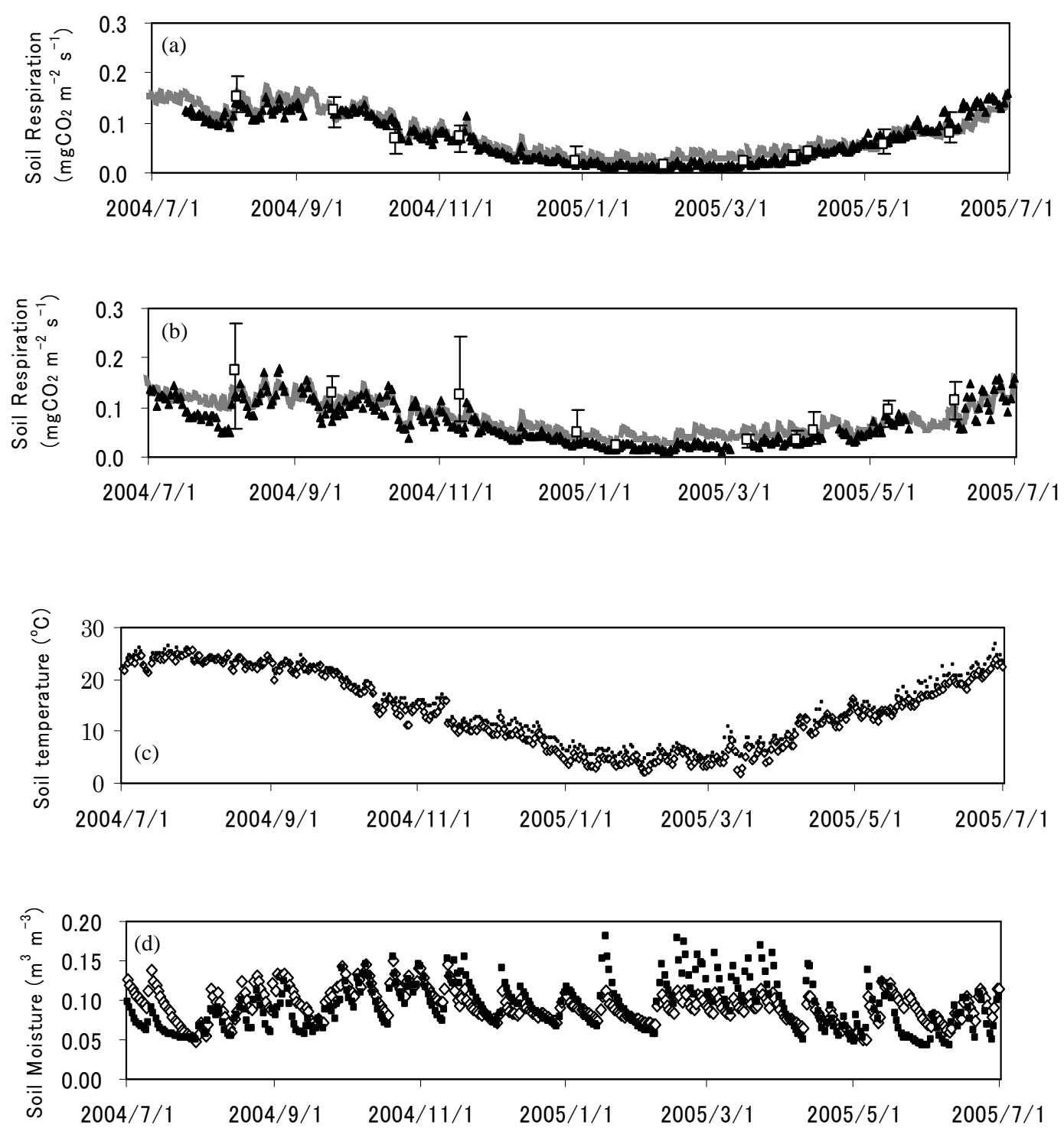

Fig. 2. Seasonal variation of soil respiration, soil temperature and soil moisture ratio in Yamashiro Experimental Forest. (a) and (b), Soil respirations in Plot V and R, respectively. Black point: Observed soil respiration by automated chamber system. Gray line: Calculated soil respiration by Eqs. (5) and (6), respectively. White square: Averaged soil respiration by manual chamber system. Bar: The range of maximum and minimum rate by manual chamber. (c) and (d), Soil temperature and soil moisture, respectively, at $5 \mathrm{~cm}$ depth. White dot: Plot V. Black dot: Plot R.
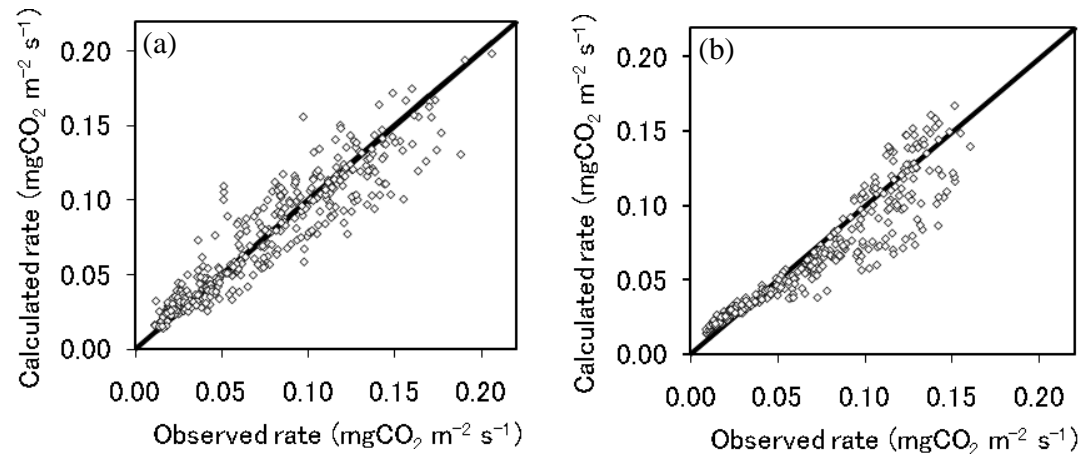

Fig. 3. Comparison of observed and calculated respiration rate in Yamashiro Experimental Forest. (a) Plot R. (b) Plot V. 

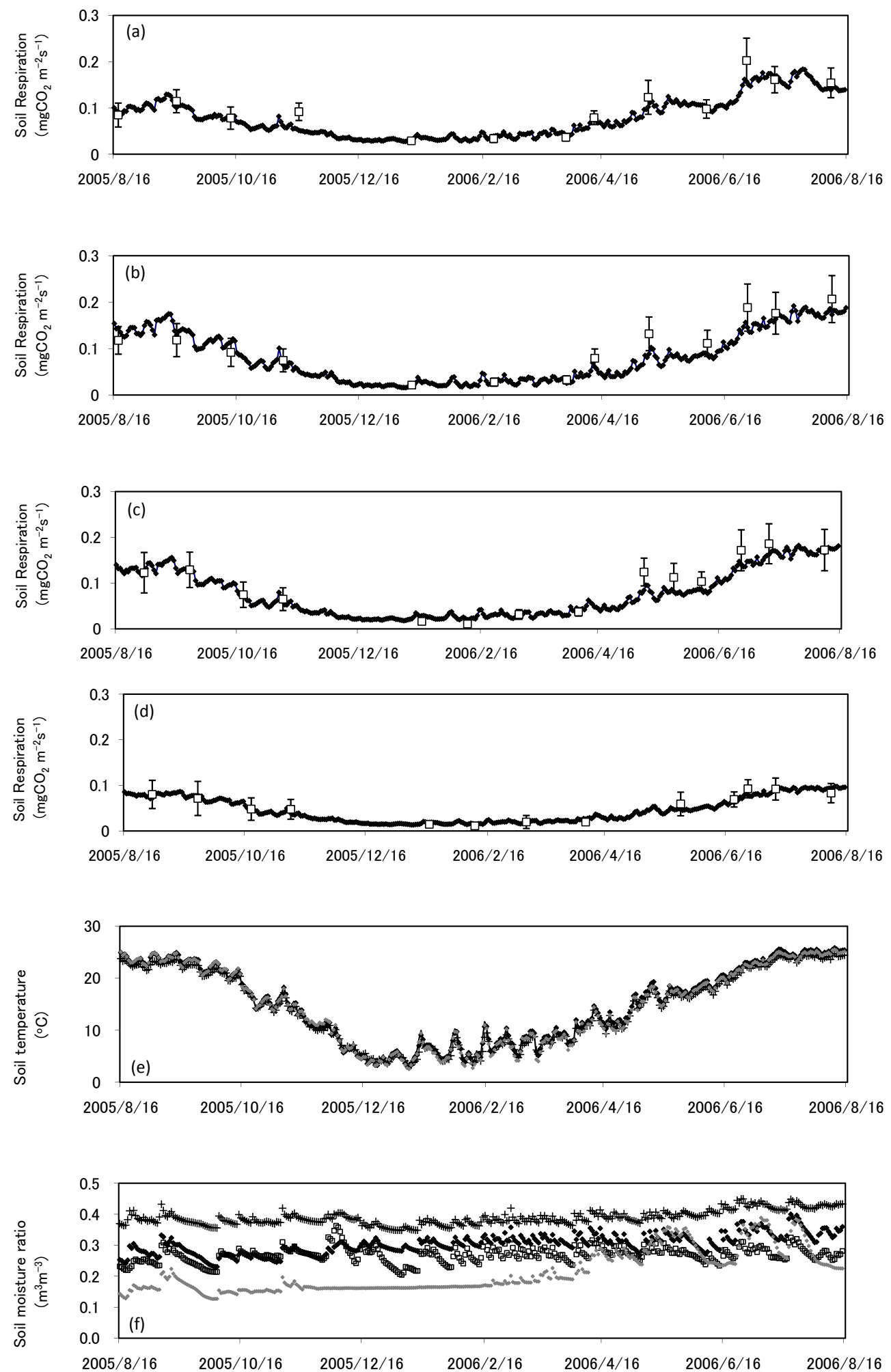

Fig. 4. Seasonal variation of soil respiration, soil temperature and soil moisture ratio in Kahoku Experimental Forest. (a, b, c and d), Soil respirations in Plot T, U, M and L, respectively Black line: Calculated soil respiration by Eqs. (7-10), respectively. White square: Averaged soil respiration by manual chamber system. Bar: The range of maximum and minimum rate by manual chamber. (e) Soil temperature at $5 \mathrm{~cm}$ depth Gray dot: Plot T. Line: Plot U. Black dot: Plot M. Plus: Plot L. (f) soil moisture ratio at 5cm depth Gray dot: Plot T. White dot: Plot U. Black dot: Plot M. Plus: Plot L. 


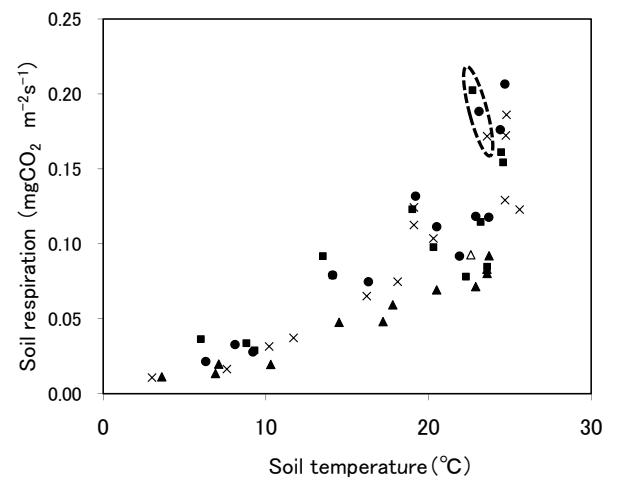

Fig. 5. Comparison of observed and calculated respiration rate in Kahoku Experimental Forest. Cross: Plot T. Black diamond: Plot U. White square: Plot M. Gray diamond:Plot L.

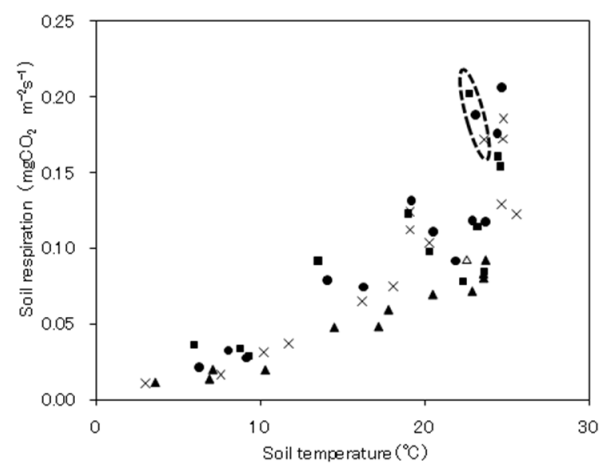

Fig. 6. Comparison between soil respiration and soil temperature in Kahoku Experimental Forest. Black square: Plot T. Black circle: Plot U. Cross: Plot M. Black and white triangle: Plot L. Three points in dotted circle and white triangle were observed on 27th June, 2006.

$23.87 \mathrm{tCO}_{2} \mathrm{ha}^{-1}$ year $^{-1}$ and $14.42 \mathrm{tCO}_{2} \mathrm{ha}^{-1}$ year $^{-1}$ for Plots T, U, M and L, respectively, in Kahoku from $16 \mathrm{Au}-$ gust 2005 to 15 August 2006 using Eqs. (7) through (10). The rates in Plots $\mathrm{M}, \mathrm{U}$ and $\mathrm{T}$ are not much different from each other. The fact that the rate in only Plot $\mathrm{L}$ is much less is in agreement with the findings of Jia et al. (2003), Mitani et al. (2006) and Kosigi et al. (2007).

Jia et al. (2003) presumed that soil moisture suppresses soil respiration at the lower slope. Figure 6 shows the relationship between $F$ and $T$ in four plots in Kahoku. The observed values for $F$ in Plots T, U and M on 27 June 2006 (dotted circle in Fig. 6) were much greater than other measured soil respiration rates at $T \approx 22^{\circ} \mathrm{C}$. This result can be attributed to elevated values of $\theta$ at this time: $328 \mathrm{~mm}$ of rain fell between 22 June 2006 and 26 June 2006, and the measurements of $F$ were made a day after this precipitation event, when $\theta$ was very large. The observed value of $F$ in Plot L on 27 June 2006 (shown as $\Delta$ in Fig. 6) was also greater than the other observed rates for Plot $\mathrm{L}$.

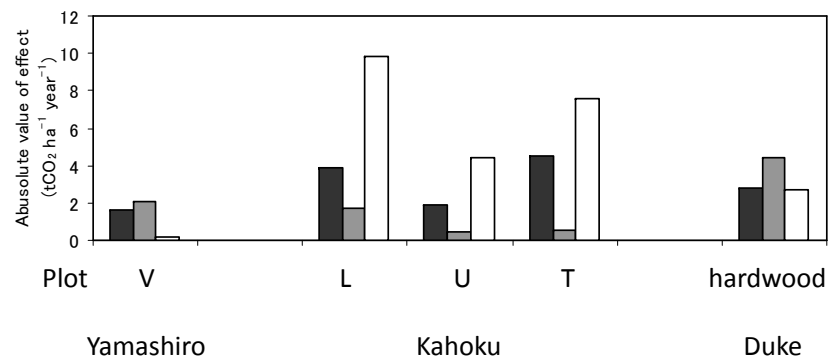

Fig. 7. Comparison of the effect on soil respiration by soil moisture $(E F(\theta))$, soil temperature $(E F(T))$ and soil property $(E F($ Soil $))$. Black block: $E F(\theta)$, Gray block: $E F(T)$, White block: $E F($ Soil).

Thus, the soil moisture is not the reason for the low respiration rate in Plot $\mathrm{L}$. The observed variation in soil temperature was very low in both experimental forests, although large variation in soil moisture was recorded in Kahoku, particularly in Plots L and T.

\section{Discussion}

The effects of soil temperature, soil moisture and soil properties on soil respiration rate, calculated using Eqs. (2) through (4), are shown in Table 3 and Fig. 7. These calculations were performed for one-year periods from 1 July 2004 to 30 June 2005 in the Yamashiro Experimental Forest and from 16 August 2005 to 15 August 2006 in the Kahoku Experimental Forest. Plots R and M were the control plots in the Yamashiro and Kahoku Experimental Forests, respectively. The results of the study by Palmroth et al. (2005) for pine plantation and hardwood areas in the Duke Forest, North Carolina, are also shown.

\subsection{Comparison of effective factors between forests}

Soil respiration rates in the Duke Forest were affected by soil temperature, soil moisture and soil properties, in decreasing order of influence (Palmroth et al., 2005). Variation in topography was small in the pine plantation and hardwood areas in the Duke Forest, which explained why $E F$ (Soil) for these areas was smaller than $E F(T)$ and $E F(\theta)$.

This order of influence in the Yamashiro was the same as that in the Duke Forest, with soil temperature having the greatest effect on soil respiration rates. However, estimates of the magnitude of the effect exerted by each parameter using Eqs. (2) through (4) yielded unusually small values for Yamashiro, particularly $E F$ (Soil). Conversely, at Kahoku, soil properties had the greatest effect on soil respiration rates, followed by soil moisture and soil temperature. One remarkable result from the Kahoku study was the very large calculated value of $E F$ (Soil).

$E F$ (Soil) depends on the differences in the parameters a, b and $\mathrm{c}$ in Eq. (1). These parameters are affected by various 
Table 3. Comparion of the effect on soil respiration by soil moisture $(E F(\theta))$, soil temperature $(E F(T))$ and soil property $(E F(\operatorname{Soil}))$.

\begin{tabular}{|c|c|c|c|c|c|c|c|c|}
\hline \multirow{2}{*}{$\begin{array}{l}\text { Experimental Forest } \\
\text { Plot }\end{array}$} & \multicolumn{2}{|c|}{ Yamashiro } & \multicolumn{4}{|c|}{ Kahoku } & \multicolumn{2}{|c|}{$\begin{array}{c}\text { Duke } \\
\text { (Palmroth et al., 2005) }\end{array}$} \\
\hline & $\mathrm{R}$ & V & $\mathrm{L}$ & M & $\mathrm{U}$ & $\mathrm{T}$ & $\begin{array}{c}\text { Pine } \\
\text { Plantation }\end{array}$ & $\begin{array}{l}\text { Hard } \\
\text { Wood }\end{array}$ \\
\hline $\begin{array}{l}\text { Estimated } F_{c} \\
\left(t \mathrm{CO}_{2} \mathrm{ha}^{-1} \text { year }^{-1}\right)\end{array}$ & 21.56 & 21.10 & 14.42 & 23.87 & 25.13 & 24.79 & 41.80 & 51.66 \\
\hline $\begin{array}{l}\text { Deifference of } F_{C} \\
\text { from the standard site } \\
\left(t \mathrm{CO}_{2} \mathrm{ha}^{-1} \text { year }^{-1}\right)\end{array}$ & $\begin{array}{l}\text { Standard } \\
\text { site }\end{array}$ & -0.46 & -9.45 & $\begin{array}{l}\text { Standard } \\
\text { site }\end{array}$ & 1.27 & 0.92 & $\begin{array}{l}\text { Standard } \\
\text { site }\end{array}$ & 9.86 \\
\hline $\begin{array}{l}\text { Effect of } \theta \\
\left.t \mathrm{CO}_{2} \mathrm{ha}^{-1} \text { year }^{-1}\right)\end{array}$ & & 1.66 & 3.89 & & -1.90 & -4.55 & & 2.79 \\
\hline $\begin{array}{l}\text { Effect of } T \\
\left(t \mathrm{CO}_{2} \mathrm{ha}^{-1} \text { year }^{-1}\right)\end{array}$ & & -2.10 & -1.74 & & -0.48 & -0.54 & & 4.40 \\
\hline $\begin{array}{l}\text { Effect of parameters } \\
\left(t \mathrm{CO}_{2} \mathrm{ha}^{-1} \text { year }^{-1}\right)\end{array}$ & & 0.20 & -9.84 & & 4.41 & 7.61 & & 2.67 \\
\hline
\end{tabular}

properties including total $\mathrm{C}$, microbial biomass and activity, root biomass and activity and porosity. These properties develop within the environment, e.g. soil temperature, soil moisture and vegetation, at each location. The soil in Yamashiro is immature and its properties have not developed at each location. Thus, the soil characteristics exhibited minimal variation and created a very small value of $E F$ (Soil) for Yamashiro. Conversely, many factors such as topography, vegetation and soil moisture varied greatly among the plots in Kahoku. Properties of the forest soil at this location developed under the conditions that in turn were influenced by the large variation of many factors. Thus, each soil type from the four plots in Kahoku had different characteristics. For example, the soil in Plot $\mathrm{T}$ had water repellency properties, which suggests peculiar microbial or root activity.

The smaller $E F$ (Soil) in Yamashiro is the result of immature soil that has not developed enough to make it different among the plots. On the other hand, the larger $E F$ (Soil) in Kahoku is the result of the soil that has developed under the conditions present at each location, thus making it different among the plots.

\subsection{Relation between $\mathbf{E F}(\theta)$ and $\mathbf{E F}($ Soil) in Kahoku}

The annual calculated soil respiration rate was almost the same $\left(23-26 \mathrm{tCO}_{2} \mathrm{ha}^{-1}\right.$ year $\left.{ }^{-1}\right)$ in three of the plots at Kahoku, with the exception of Plot $\mathrm{L}$. The positive and negative values of $E F(\theta)$ and $E F$ (Soil) differed from each other in every plot in Kahoku. This suggests that the effects of $E F(\theta)$ and $E F$ (Soil) cancel each other out in Kahoku, and that soil respiration rates become nearly equal. This discussion can be applied for $E F(\theta)$ and $E F(T)$ in Plots $\mathrm{R}$ and $\mathrm{V}$ in Yamashiro.

$F$ in Plot L was much less than $F$ in the other three plots in Kahoku. Soil respiration was increased after heavy precipitation events in every plot in Kahoku, as shown in Fig. 6. The value of $E F(\theta)$ in Plot $\mathrm{L}$ is positive, $3.89 \mathrm{tCO}_{2} \mathrm{ha}^{-1}$ year $^{-1}$, and indicates that soil moisture accelerated soil respiration in Plot L. In contrast, the value of $E F$ (Soil) in Plot L is negative, at $-9.84 \mathrm{tCO}_{2} \mathrm{ha}^{-1}$ year $^{-1}$, and indicates that soil property decelerates soil respiration. Thus, it is concluded that the restricting factor in Plot $\mathrm{L}$ is soil respiration, not the wet soil condition. The peculiar characteristics of the soil in Plot L included many fist-sized stones that rolled to the base of the slope and accumulated there. Consequently, the soil volume contributing to soil respiration was small. This characteristic is supposed to minimize soil respiration in Plot $\mathrm{L}$.

\section{Conclusions}

This study concludes as follows:

1. The cause of the smaller $E F$ (Soil) in Yamashiro was immature soil and the fact that the soil had not developed enough to be different among the plots. Whereas the cause of the larger $E F$ (Soil) in Kahoku was the fact that the soil had developed under the conditions at each location and was different among the plots.

2. The positive and negative effects of soil moisture and soil properties, $E F(\theta)$ and $E F$ (Soil), differed from each other in every plot in Kahoku and Yamashiro. Consequently, their effects cancelled out each other, possibly leading to nearly equal annual rates of soil respiration in Plots $\mathrm{T}, \mathrm{U}$ and $\mathrm{M}$ in Kahoku. This can be applied for $E F(\theta)$ and $E F(T)$ in Plots $\mathrm{V}$ and $\mathrm{R}$ in Yamashiro, respectively.

3. The restricting factor of soil respiration in Plot $\mathrm{L}$ is judged to be the soil property, not the wet soil condition. 
Acknowledgements. This study was supported by JSPS A3 Foresight Program, the Global Environment Research Account for National Institutes Long-term Monitoring of Carbon Flux and Promotion of Data Network in Asian Terrestrial Ecosystems and Research Fund (Evaluation, Adaptation and Mitigation of Global Warming in Agriculture, Forestry and FisheriesFResearch and Development) by Ministry of Agriculture, Forestry and Fisheries of Japan.

Edited by: J. Chen

\section{References}

Araki, M., Torii, A., Kaneko, S., and Yoshioka, J.: Estimation of the soil water holding capacity and soil water content in a granite small watershed, Applied Forest Science, (in Japanese), 6, 4952, 1997.

Dannoura, M., Kominami, Y., Tamai, K., Jomura, M., Miyama, T., Goto, Y., and Kanazawa, Y.: Development of an automatic chamber system for long-term measurements of $\mathrm{CO}_{2}$ flux from roots, Tellus, 58B, 502-512, 2006.

Davidson, E. A., Belk, E., and Boone, R. D.: Soil water content and temperature as independent and confounded factors controlling soil respiration in a temperate mixed hardwood forest, Glob. Change Biol., 4, 217-227, 1998.

Davidson, E. A., Savage, K., Verchot, L. V., and Navarro, R.: Minimizing artifacts and biases in chamber-based measurements of soil respiration, Agric. and For. Meteorol., 113, 21-37, 2002.

Fang, C., Moncrieff, J. B., Gholz, H. L., and Clark, K. L.: Soil CO efflux and its spatial variation in a Florida slash pine plantation, Plant Soil, 205, 135-146, 1998.

Goto, Y., Kominami, Y., Miyama, T., Tamai, K., and Kanazawa ,Y.: Aboveground biomass and net primary production of a broadleaved secondary forest in the southern part of Kyoto Prefecture, central Japan, Bull. of the For. and For. Prod. Res. Inst.,(in Japanese with English abstract), 2, 115-147, 2003.

Goto, Y., Tamai, K., Miyama, T., and Kominami, Y.: Stand structure and dynamics during a 5-year period in a broad-leaved secondary forest in southern Kyoto Prefecture, central Japan, Jpn. J. Ecol., (in Japanese with English summary), 54, 71-84, 2004.

Hanson P. J., Edwards, N. T., Garten, C. T., and et al.: Separating root and soil microbial contributions to soil respiration in a forest ecosystem, Biogeochemistry, 48, 115-146, 2000.

Hanson, P. J., Wullschleger, S. D., Bohlman, S. A., and Todd, D. E.: Seasonal and topographic patterns of forest floor $\mathrm{CO}_{2}$ efflux from an upland oak forest, Tree Physiol., 13, 1-15, 1993.

Hashimoto, T., Miura, S., Ikeda, S., and Shichi, K.: Estimation of spatial variation of soil $\mathrm{CO}_{2}$ efflux from tree index, J. Jpn. For. Soc., (in Japanese with English summary), 90, 386-390, 2008.

Ishizuka S., Sakata, T., Sawata, S., Ikeda, S., Takenaka C., Tamai N., Sakai H., Shimizu, T., Kan-na, K., Onodera, S, Tanaka, N., and Takahashi, M.: High potential for increase in $\mathrm{CO} 2$ flux from forest soil surface due to global warming in cooler areas of Japan, Ann. For. Sci., 63, 537-546, 2006.
Jia, S., Akiyama, T., Mo, W., Inatomi, M., and Koizumi, H.: Temporal and spatial variability of soil respiration in a cool temperature broad-leaved forest. 1.Measurement of spatial variance and factor analysis, Jpn. J. Ecol., 53, 13-22, 2003. (in Japanese with English abstract)

Kobayashi, M. and Shimizu, T.: Soil water repellency in a Japanese cypress plantation restricts increases in soil water storage during rainfall events, Hydrol. Process., 21, 2356-2364, 2007.

Kominami, Y., Miyama, T., Tamai, K., Nobuhiro, T., and Goto, Y.: Characteristics of $\mathrm{CO}_{2}$ flux over a forest on complex topography, Tellus, 55B, 313-321, 2003.

Kosugi, Y., Mitani, T., Itoh, M., Noguchi, S., Tani, M., Matso, N., Takanashi, S., Ohkubo, S., and Nik, A. R.: Spatial and temporal variation in soil respiration in a Southeast Asian tropical rainforest, Agric. For. Meteorol., 147, 16-34, 2007.

Mitani, T., Kosugi, Y., Osaka,K., Ohkubo,S., Takanashi, S., and Tani, M.: Spatial and temporal variability of soil respiration rate at a small watershed revegetated with Japanese cypress, J. Jpn. For. Soc., (in Japanese with English summary), 88, 496-507, 2006.

Nobuhiro, T., Tamai, K., Kominami, Y., Miyama, T., Goto, Y., and Kanazawa, Y.: Development of IRGA enclosed-chamber system for soil $\mathrm{CO}_{2}$ efflux measurement and its application to a spatial variation measurement, J. For. Res., 8, 297-301, 2003.

Ohashi M. and Gyokusen K.: Temporal change in spatial variability of soil respiration on a slope of Japanese ceder (Cryptomeria japonica D. Don) forest, Soil Biol. Biochemi., 39, 1130-1138, 2007.

Palmroth, S., Maier, C. A., McCarthy, H. R., Oishi, A. C., Kim, H.-S., Johnsen, K. H., Katul, G. G., and Oren, R.: Contrasting responses to drought of forest floor $\mathrm{CO} 2$ efflux in a Loblolly pine plantation and a nearby Oak-Hickory forest, Glob. Change Biol., 11, 1-14, 2005.

Sotta, E. D., Veldkamp, E., Guimarães, B. R., Paixão, R. K., Ruivo, M. L. P., and Almeida, S. S.: Landscape and climatic controls on spatial and temporal variation in soil $\mathrm{CO}_{2}$ efflux in an Eastern Amazonian rainforest, Caxiuanã,Brazil, For. Ecol. Manage., 237, 57-64, 2006.

Sugawara, T., Kumagai, T., Ohashi, M., Morooka, T., and Suzuki, M.: Nighttime $\mathrm{CO}_{2}$ flux over a Bornean tropical rainforest, J. Jpn. Soc. Hydrol. Water Resour., 18, 64-77, 2005.

Tamai, K., Kominami, Y., Miyama, T., and Goto, Y.: The estimation of time series data for soil respiration based on soil temperature and soil moisture content ratio and its spatial variations in a small mountainous catchment: in the case of weathered granite region in southern Kyoto Prefecture, J. Jpn. For. Soc., (in Japanese with English summary), 87, 331-339, 2005a. .

Tamai, K., Kominami, Y., Miyama, T., and Goto, Y.: Temporal fluctuations in the $\mathrm{CO}_{2}$ efflux on a forest floor-the case of an extremely immature forest soil, J. Agric. Meteorol., 60, 773-776, 2005b.

Yamashiro town history editorial board: Yamashiro town history text part -, pp. 999, Yamashiro town hall, (in Japanese), 1986. 